\title{
GONAD DEVELOPMENT AND INITIAL SPAWNING OF SELECTED THIRD GENERATION CORAL TROUT (Plectropomus leopardus)
}

\author{
Muzaki A*, Yudha HT, Giri NA, Haryanti and Sembiring SBM \\ Institute for Mariculture Research and Fisheries Extention, Ministry of Marine Affairs and \\ Fisheries, Indonesia
}

\begin{abstract}
Coral trout (Plectropomus leopardus) is one of the grouper species with high economic value. The demand for fingerlings has been considerably increased in recent years. Dependence on the wild broodstock should be reduced gradually and replaced with domesticated from hatchery production. Institute for Mariculture Research and Fishes Extension (IMRAFE) has succeeded in coral trout culture and selected domesticated broodstock using a fast-growth marker and now has a third-generation (F3) of coral trout. Observation of gonad development and initial spawning of third-generation (F3) coral trout was carried out. The study aimed to understand gonadal development and initial spawning of coral trout F3 as an alternative for wild broodstock used in grouper hatchery activities. The study used 100 fishes of 31 months old coral trout F3 and observed for 11 months from January - November 2017. The research includes analysis of coral trout F3 gonad development, cultured and initial spawned of coral trout F3. The result shown in the population of coral trout F3 was male, transition, and female. Stage of female gonad maturation was III, IV, and V. The fecundity range $175.478-1.777 .988$ eggs, and coral trout F3 was spawned with quality still low. Increasing spawning quality can be done by improving feed management and hormonal stimulation.
\end{abstract}

Keywords: Gonad development, initial spawning, coral trout, third-generation (F3)

\section{Introduction}

Coral trout Plectropomus leopardus is an emerging exported grouper commodity in Indonesia. The demand for coral trout fingerlings has considerably increased in recent years, particularly from the central area for grouper hatcheries in Bali (Asih et al, 2021). Coral trout have been artificially spawned, and the larvae have been reared since 2005 in Institute for Mariculture Research and Fishes Extension (IMRAFE) Gondol - Bali (Suwirya, 2005).

In implementing wild broodstock in the fish farming business, dependence on the wild should be reduced gradually and replaced with domesticated stock from hatchery production, and followed by a selective breeding program (Aliah et al, 2006). Information on the genetic character of the broodstocks is required for the improvement of grouper genetic quality. The genetic marker that controls a character could support the effectiveness and efficiency of the selective breeding program. This technique would be more accurate in selection results and shorter in selection time (Cintamulya, 2011).

Efforts to improve the genetic characteristics of coral trout grouper were carried out by identifying the fast-growing loci obtained at the PL-03 locus using the microsatellite/SSRs (Simple Sequence 
Repeats) method (Sembiring et al, 2012). The PL-03 locus was then applied to the cultivated broodstock (F-1 and F-2) to obtain better coral trout seeds. In 2016, the population of the selected coral trout F3 was obtained. Based on the analysis of genetic diversity of F3 using the microsatellite method, it turns out that the selected coral trout F3 is still suitable for use as broodstock candidates for grouper hatchery. Previous research has been conducted on wild \& F1 coral trout (Andamari, 2005; Andamari et al, 2007; Andamari \& Suwirya, 2010; Sembiring et al, 2014). But the data on the reproductive aspects of the coral trout F3 is still very limited, therefore it is necessary to conduct research to determine the reproductive performance of the coral trout F3.

The study aimed to understand gonadal development and initial spawning of coral trout F3 as an alternative for wild broodstock used in grouper hatchery activities.

\section{Material and Methods}

\section{Test fish}

The study was conducted at Institute for Mariculture Research and Fisheries Extention Bali, Ministry of Marine Affairs and Fisheries Indonesia, for 11 months of observation from January to November 2017. The sample was 100 fishes of 31 months of third-generation (F3) coral trout from selected broodstock F2 that carried a fast growth locus (Locus PL-03). The selected coral trout F3 with a total length of $41.4 \pm 2.6 \mathrm{~cm}$ and a body weight of $1234 \pm 297 \mathrm{~g}$.

\section{Rearing of selected coral trout F3}

Selected coral trout $\mathrm{F} 3$ was reared in a $75 \mathrm{~m}^{3}$ of concrete tank equipped with an aeration system and $300-400 \%$ of water exchange. The broodstock is fed with fresh fish and squid once daily at satiation around 3-5\% of its biomass. Vitamin C, E, and mix were used at $5 \mathrm{~g} \mathrm{Kg}^{-1}$ of fed. Every 10 days, broodstock was bathed in freshwater for a few seconds to prevent external parasite infection. For growth observation, 20 fishes were weighed and measured every month, while survival was determined at the end of the study.

\section{Gonad development of selected coral trout F3}

The Ovarian developments and histological observation was carried out in April, July, and October 2017. All specimens were measured for total length $(\mathrm{cm})$ and body weight $(\mathrm{g})$, then the abdomen was dissected to collect gonads and fixed in Bouin's solution for further histological analysis. Gonad maturity index, sex, and fecundity were observed to determine gonad development of selected coral trout F3.

\section{Spawning of selected coral trout F3}

Selected coral trout F3 was massively and naturally spawned following the new phase of lunar cycle. Egg collectors were installed at the tank. When spawning occurs, the eggs are carefully harvested the following day and then incubated in the particular tank. Spawning frequency, total eggs produced, and fertility rate was recorded during the spawning season. 


\section{Observed parameters and data analysis}

The parameters observed in this study included: Growth (total length, body weight), survival, spawning frequency, total eggs produced, fertility rate, gonad maturity index, sex, gonad stages, and egg fecundity. The data obtained were analyzed descriptive and presented in the form of images, tables, and graphs.

\section{Result and Discussion}

\section{Rearing of selected coral trout F3}

Selected coral trout were growing very well during observation. The average bodyweight of selected coral trout F3 at the end of the observation was $1695 \mathrm{~g}$, increased by $520 \mathrm{~g}$ from $1075 \mathrm{~g}$ at the beginning of the observation. Likewise, the average total length increased by $3.1 \mathrm{~cm}$ from $40.8 \mathrm{~cm}$ to $43,9 \mathrm{~cm}$. The survival of selected coral trout F3 at the end observation was $65 \%$, or as many as 65 fishes were still alive. Increase in the body weight of coral trout F-1 by $400-700 \mathrm{~g}$ for 9 months of rearing periods (Sembiring et al, 2015).

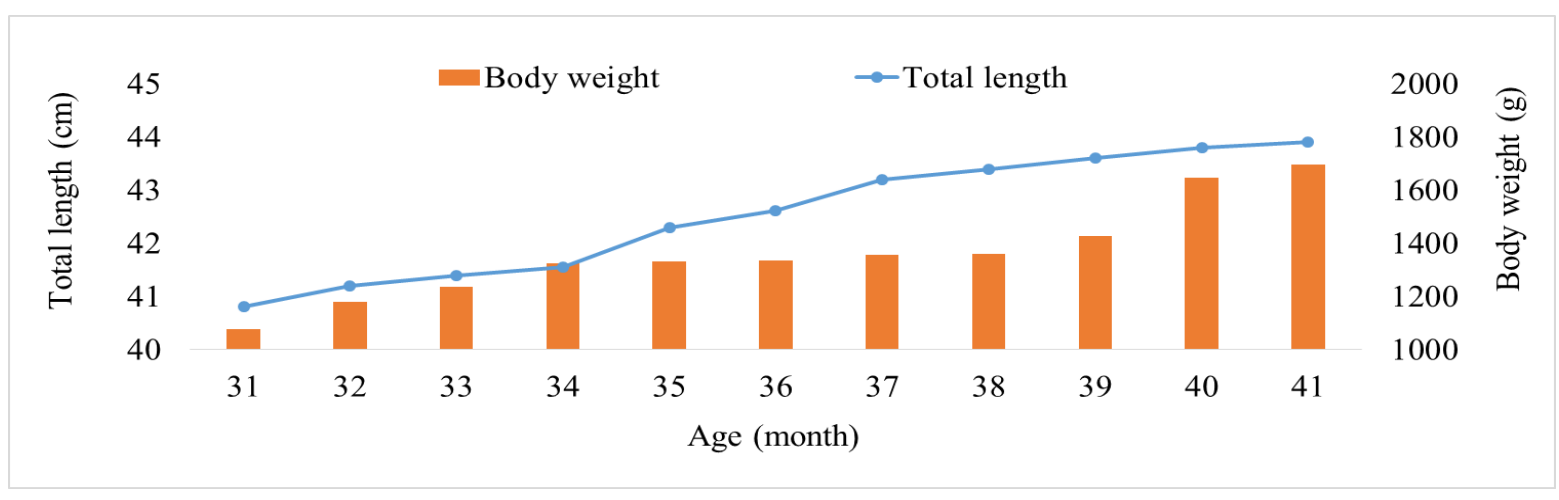

Figure 1: Growth performance (total length and body weight) of selected coral trout F3 during observation

\section{Gonadal development of selected coral trout F3}

The gonadal development data of selected coral trout F3 is shown in Table 1. Observations revealed that most of the fish were female, 1 transition fish, and 1 male fish. Gonad maturity index ranged from 0.6 to 3.8, with oocyte maturity level reaching stage I-V and fecundity ranging from 191198-1357188 eggs. From the histological analysis, it was clear that several oocyte stages were present in the female gonads. In contrast, the transitional fish were shown by the development of oocytes and spermatozoa in one gonad. In male fish, only spermatozoa are seen in the gonads.

Table 1: Observation of gonad development of selected coral trout F3

\begin{tabular}{llll}
\hline \multirow{2}{*}{ Parameter } & \multicolumn{2}{l}{ Observation Time } & Oktober \\
\cline { 2 - 4 } & April & July & $42.8 \pm 2.3$ \\
\hline Total Length $(\mathrm{cm})$ & $37 \pm 0.9$ & $41.2 \pm 0.8$ & $1532 \pm 225.7$ \\
\hline Body weight $(\mathrm{g})$ & $876 \pm 69.9$ & $1420 \pm 153.6$ & \\
\hline $\begin{array}{l}\text { Gonad maturity } \\
\text { index }(\%)\end{array}$ & $0.7-3.3$ & $0.6-3.8$ & $2.2-7.6$ \\
\hline
\end{tabular}




\begin{tabular}{llll}
\hline Male & 0 & 1 & 0 \\
\hline Transition & 1 & 0 & 0 \\
\hline Female & 4 & 4 & 5 \\
\hline Gonad stages & $\mathrm{V}$ & IV \& V & V \\
\hline Fecundity (eggs) & $193.198-452.318$ & $642.856-1.241 .840$ & $813.527-1.357 .188$ \\
\hline
\end{tabular}
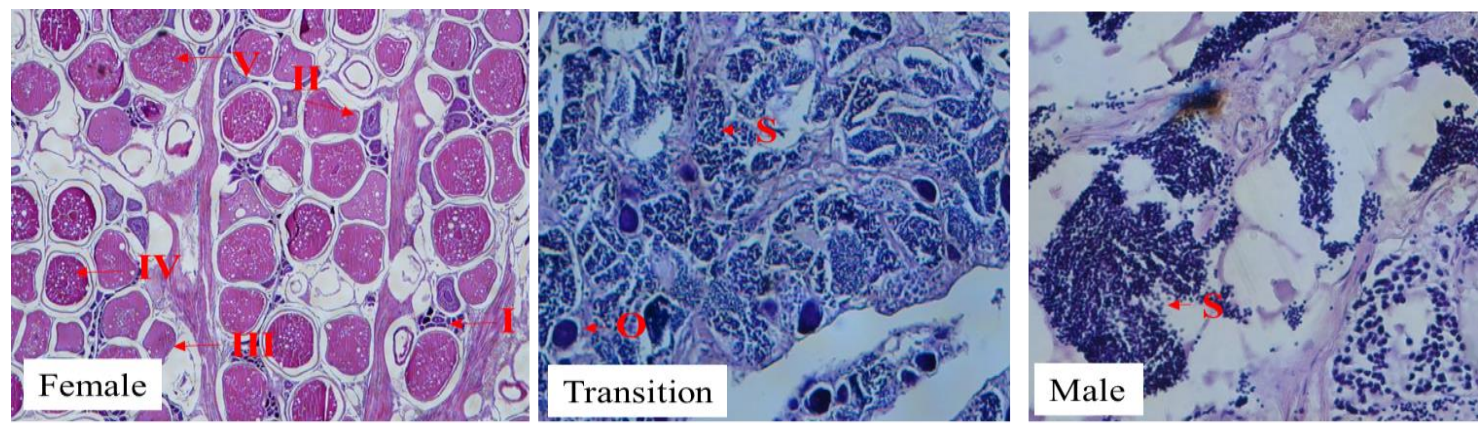

Figure 2: Gonad histology of selected coral trout F3 (I) oosit maturity level 1; II) oosit maturity level 2; III) oosit maturity level 3; IV) oosit maturity level 4; V) oosit maturity level 5; O) Oosit; S) Spermatosit

\section{Spawning of selected coral trout F3}

During observations, the selected coral trout F3 spawned naturally twice i.e., October and November, with a frequency of a day of spawning. The eggs produced were 131.677 eggs in October and 118.333 eggs in November, but they were unfertilized. The low number of eggs produced indicates that few females were spawning. The absence of fertilized eggs may occur due to the limited number of functional males in this population. However, the occurrence of spawning indicates that the selected coral trout F3 was ready to be used as broodstock in hatchery activities.

Coral trout is a protogynous hermaphrodite fish (Andamari et al, 2007). Protogynous hermaphrodites occur when the fish gonads differentiate from the female phase to the male (Effendie, 1997). The female maturity stage can be classified into immature and mature depending on the gonad development, indicated by the presence or absence of vitellogen. Male fish do not go through the juvenile phase because they develop from adult females through sex changes. The transitional stage is marked by sperm cells in the ovaries (Ferreira, 1995). Sex change in some reef fish was controlled sociodemographically, the absence of a male from the population causes a sex change in the dominant (largest) female (Saphiro 1989). In this study, the population of coral trout F3 has the same age, so there is a possibility that one of the dominant females will change into a male.

From the observations of the gonads, it was found that the selected coral trout F3 had oosit development with maturity levels IV and V. This indicates that the population has formed female fish, which are included in the mature stage. As evidenced from the 15 dissected fishes, 13 were identified as female fish, one fish in a transitional phase, and one male fish. The gonadal maturity index showed varying values. A low value indicates the fish is in a transitional or male stage, while a high value indicates females. In a previous study, coral trout reached gonad maturity if it had a value $>1.5 \%$, although the gonad maturity index does not show a direct relationship with the length or weight of fish (Andamari et al, 2007). 
The minimum size when the fish first reproduces is estimated at a length of $32-36 \mathrm{~cm}$ or about 2-3 years old (Ferreira, 1995). In this study, the F3 grouper (locally call as Sunu) average total length is $41.4 \pm 2.6 \mathrm{~cm}$ and $1234 \pm 297 \mathrm{~g}$ of body weight at 41 months spawned for the first time. Spawning season is correlated with the lunar cycle and water temperature (Sadovy \& Eklund, 1999; Colin, 1992). Environmental stimulation can also trigger fish to spawn, The sudden changes in the environmental parameters in captivity such as fluctuation of water temperature, salinity, and photoperiod, often trigger several fish to spawn, as in yellow perch Perca flavescens (Starzynski \& Lauer, 2015), striped bass Morone saxatilis (Henderson-Arzapalo \& Colura, 2011), yellowtail Seriola quinqueradiata (Mushiake et al, 1998),

The number of eggs produced was still at a low quantity and has been unfertilized because there were only a few females that spawned, and a lack of males was found. Selected coral trout F3 was the same batch population, so they have the same age as most of the selected coral trout F3 still in the female phase, only a few were in the transitional stage or become males. Improving the reproductive quality of the coral trout can be done through hormonal induction as in previous study, induction of LHRH analog in P. leopardus (Suwirya et al, 2006), aromatase inhibitor and oodev in P leopardus (Yudha et al, 2017), androgen mixture testosterone in potato grouper Epinephelus tukula (Yeh et al, 2003), Human chorionic gonadotropin in blue spotted grouper E. fario (Kuo et al, 1988), 17- $\alpha$ Methyltestosterone in dusky grouper E. marginatus (Glamuzina et al, 1998).

\section{Conclusion}

In the population of selected coral trout F3, there are male, transitional, and female fish with gonad maturity levels reaching stages III, IV, and V with fecundity produced ranging from 175,478 $1,777,988$ eggs. The selected coral trout F3 has spawned, but the eggs have been unfertilized. The selected coral trout F3 (41 months) was technically available as broodstock for grouper hatchery.

\section{Acknowledgments}

The authors gratefully thank all researchers and technicians of the Biotechnology Laboratory and Grouper Hatchery at the Institute for Mariculture Research and Fisheries Extension who supported this research. This study was part of a research project of the Ministry of Marine Affairs and Fisheries. Indonesia.

\section{References}

Asih, Y.A., Sudewi, Nasukha, A., and Giri, N.A. (2021). Coral trout Plectropomus leopardus aquaculture research and fingerling production in Indonesia. Aquaculture Asia Magazine, 25(1), 2326

Aliah, R.S., Wahidah, Sumantadinata, K., Nugroho E., and Carman, O. (2006). Genetic characterization of the first generation humpback grouper (Cromileptes altivelis) from the domestication program. Jurnal Akuakultur Indonesia, 5(1), 87-95

Andamari, R. (2005). Reproductive aspects of coral trout grouper (Plectropomus leopardus) in the Sulawesi and Maluku sea. Jurnal Penelitian Perikanan Indonesia, 11(7), 7-12

Andamari, R., Sembiring, S.B.M., and Permana, I.G.N. (2007). The aspect of leopard coral grouper (Plectropomus leopardus) reproduction in Indonesia. Indonesian Aquaculture Journal, 2(1), 51-57 
Andamari, R., and Suwirya, K. (2010). Reproduction performance of wild broodstock coral trout (Plectropomus leopardus). Indonesian fisheries Research Journal, 16(1), 41-47

Cintamulya, I. (2011). Application of Microsatellite/SSRs (Simple Sequence Repeats) molecular markers to support plant breeding programs. Berkala Penelitian Hayati Edisi Khusus, 7A, 161-165

Effendie, M.I. (1997). Fisheries Biology. Yayasan Pustaka Nusatama. Yogyakarta. 163 p

Ferreira, B.P. (1995). Reproduction of the common coral trout Plectropomus leopardus from the central and northern Great Barrier Reef. Bulletin Marine Science, 56(2), 653-669

Glamuzina, B., Glavic, N., Skaramuca, B., and Kozul, V. (1998). Induced sex reversal dusky grouper Epinephelus marginatus (Lowe). Aquaculture, 74, 113-126

Henderson-Arzapalo, A., and Colura, R.L. (2011). Laboratory maturation and induced spawning of striped bass Morone saxatilis. Progress Fisheries Cultivation, 49(1), 60-63

Kuo, C.M., Ting, Y.Y., and Yeh, S.L. (1988). Induced Sex Reversal and Spawning of Blue Spotted Grouper, Epinephelus fario. Aquaculture, 74, 113-126

Mushiake, K., Kawano, K., Kobayashi, T., and Yamasaki, T. (1998). Advanced spawning in yellowtail, Seriola quinqueradiata, by manipulations of the photoperiod and water temperature. Fisheries Science, 64(5), 727-731

Sadovy, Y., and Eklund, A.M., (1999). Synopsis of biological information on Epinephelus striatus Bloch, 1972, the Nassau grouper, and E. itajara Lichtenstein, 1822 the jewfish. U.S. Department of Commerce, NOAA Technical Report NMFS 146, and FAO Fisheries

Sembiring, S.B.M., Haryanti, Suwirya, K., Wardana, I.K., Sutarmat, T., and Yudha, H.T. (2012). The use of fast-growing genetic markers for the production of coral trout grouper broodstock candidates, Plectropomus leopardus in the selection program. Jurnal Riset Akuakultur, 7(1), 01-09

Sembiring, S.B.M., Hutapea, J.H, and Muzaki, A. (2015). Production of functional male broodstock of coral trout grouper (Plectropomus leopardus). Jurnal Ilmu dan Teknologi Kelautan Tropis, 7(1), $123-128$

Shapiro, D.Y. (1989). Sex change as an alternatife life-history style. In M.N Bruton, ed. Alternative life-history style of Animals. Kluwer Academic Publisher. Dordrecht. 177-195

Starzynski, D., and Lauer, T.E. (2015) How temperature affects timing and duration of yellow perch spawning in the Indiana waters of Lake Michigan. Journal Freshwater Ecology, 30(3), 445-453

Suwirya, K. (2005). Spawning and larval rearing of coral trout at Gondol. SPC Live Reef Fish Information Bulletin. 13 - January 2005

Suwirya, K., Priyono, A., Giri, N.A., and Setyadarma, T. (2006). Gonad maturation of coral trout grouper (Plectropomus leopardus) with LHRH-analog hormone. Jurnal Riset Akuakultur, 1(3), 411417

Yeh, S.Y., Dai Q.C., Chu, Y.T., Kuo, C.M., Ting, Y.Y., and Chang, C.F. (2003). Induced sex change, spawning and larviculture of potato grouper, Epinephelus tukula. Aquaculture, 228, $371-381$

Yudha, H.T., Sudrajat, A.O., and Haryanti. (2017). Effect of stimulation of aromatase inhibitor and oodev hormones on sex changes and gonadal development of coral trout grouper, Plectropomus leopardus. Jurnal Riset Akuakultur, 12 (4), 325-333 